\title{
Thermal variation for growth of zoospores of Albugo spp.
}

\section{Rafaela Souza Alves Fonseca ${ }^{1}$, Milton Luiz da Paz Lima ${ }^{1}$, Paula Rodrigues Neves ${ }^{1}$, Natanael Marcos Lemes ${ }^{1}$, Jennifer Decloquement ${ }^{2}$}

\author{
${ }^{1}$ Instituto Federal Goiano, Campus Urutaí, Urutaí, Goiás, Brasil. E-mail: rafaelaalvesf@ hotmail.com, \\ paularodriguesneves@hotmail.com,natanaelmarcos20@gmail.com, milton.lima@ifgoiano.edu.br. \\ ${ }^{2}$ Institut Universitaire de Technologie de Béthune, Béthune Cédex, France. E-mail: jennifer.decloquement@laposte.net
}

Recebido: 30/04/2017; Aceito: 17/01/2018

\begin{abstract}
The objective of this work was to identify the time of the thermal shock that promotes the greater release of zoospores/sporangia. The experiments were carried out with five treatments, varying the thermal variation time $\left(20^{\prime}, 30^{\prime}, 40^{\prime}, 50^{\prime}\right.$ and $\left.60^{\prime}\right)$ of sporangia suspension of $7.10^{5}$ sporangia $\mathrm{mL}^{-1}$ under $5^{\circ} \mathrm{C}$ temperature. The incidence of sporangia germinated by 20 times whose It was evaluated 100 units at random, using an optical microscope at 40 times magnification. The F and Tukey test were used to compare the means. The sexual phase (presence of oospores) was identified in the isolate derived from purslane. In purslane leaves (infected by Albugo portulacae) the time of 20-30' promoted a greater number of zoospores released, whereas for the isolate from amarantus (infected by A. bliti) the time of 30' promoted statistically the highest release of zoospores; for the isolate from leaves of "jetirana" (infected by A. ipomoeae-panduratae) the time of 30-50" promoted greater release of zoospores; and finally the isolate from "onze-horas" leaves (infected by A. portulacae) the time of 30-40" statistically promoted the highest percentage of release of zoospores, It was demonstrating a differential behavior per host in the release of zoospores. The thermal shock time that promoted the highest amount of released zoospores (38\%) was observed for the purslane-Albugo portulacae and "onze horas"-A. portulacae pathosystem.
\end{abstract}

Palavras-chave: white rust, sporangia, thermal shock, release.

\section{Choque térmico para formação de zoósporos de Albugo spp.}

\section{RESUMO}

O objetivo deste trabalho foi identificar o tempo de choque térmico para liberação de zoósporos por esporângio. Foram coletadas amostras foliares sintomáticas de cinco tratamentos o qual variou-se o tempo de choque térmico $\left(20^{\prime}, 30^{\prime}, 40^{\prime}, 50^{\prime}\right.$ e $\left.60^{\prime}\right)$, de suspensão de $7.10^{5}$ esporângios $\mathrm{mL}^{-1}$ sob temperatura de $5{ }^{\circ} \mathrm{C}$. Avaliou-se a incidência de esporângios que formaram zoósporos, avaliando 100 unidades aleatoriamente, utilizando microscópio ótico no aumento de 40X. Utilizou-se o teste $\mathrm{F}$ e Tukey para comparação das médias. Foi identificado a fase sexual (presença de oósporos) no isolado oriundo de beldroega. Em folhas de beldroega (infectado por Albugo portulacae) o tempo de 20-30' promoveu maior número de zoósporos liberados, já para o isolado oriundo de amarantus (infectadas por A. bliti) o tempo de 30' minutos promoveu estatisticamente a maior liberação de zoósporos; para o isolado oriundo de folhas de jetirana (infectada por A. ipomoeae-panduratae) o tempo de 30-50' promoveu maior liberação de zoósporos; e por fim o isolado oriundo de folhas de onze-horas (infectado por A. portulacae) o tempo de 30-40' promoveram estatisticamente a maior porcentagem de liberação de zoósporos, demonstrando um comportamento diferencial por hospedeiro na liberação de zoósporos. O tempo de choque térmico que promoveu a maior quantidade de zoósporos liberados (38\%) foi observada para o patossistema beldroega-A. portulacae e onze-horas-A. portulacae.

Key words: ferrugem branca, esporângio, choque térmico, liberação. 
White blister rust is caused by the fungus Albugo spp. (Chromista Kingdom, Family Albuginaceae), presents 2848 records of occurrences in hosts in the world deserving highlighting the records infecting amaranthus - A. bliti (Syn. Wilsoniana bliti), radish, arugula, cruciferous in general - A. cruciferarum (Syn. A. candida), "corda de viola", "jetirana" and sweet potato - A. ipomoeae-panduratae and sunflower and gerbera - A. tragopogonis Syn. Pustula tragopogonis) (FARR; ROSSMAN, 2018). In nature, the formation of chain sporangia, which can germinate directly forming mycelium or produce biflagellated zoospores, is observed. Typically, chlorotic lesions present on the upper face of the leave, which was forming whitish visible pustules on the underside, with the presence of dustiness (signals). The pustules are covered by a mass of white, abundant and pulverulent, formed by sporangia of the pathogen. Necrotic areas of reddishbrown color develop around pustules (KIMATI et al., 1995).

In infected tissues, they produce intercellular hyphae with haustoria in the form of globular vesicles. The spread mainly occurs by winds and rains, infected branches and insects. Temperatures in the range of 23$25{ }^{\circ} \mathrm{C}$ and relative humidity around $85 \%$ favor the occurrence of the disease. Sporangium germination and fungus penetration occur more effectively during cold nights (threshold $\pm 10{ }^{\circ} \mathrm{C}$ ) (KIMATI et al., 1995). It Albugo spp. can be reproduced asexually via zoosporangia, which release flagellated motile zoospores. On the surface of a plant leaves, zoospores settle in stomata, and each extends a germ tube into the stomatal chamber (HOLUB et al., 1995).

There are several cultivars in the field susceptible to white blister rust of economic importance, such as arugula, sweet potatoes and radish, which can cause great foliar damage. However, several weeds, such as rope, amaranthus, "jetirana", among others, have been recognized recurrent infections in the municipality of Urutaí.

In plant infected, when dehydrated the pustules could to contain masses of zoospores that upon rehydration in water droplets release 4-6 zoospores that can swim to stomatal openings, encyst and produce a germ tube which will extend into the sub-stomatal chamber and penetrate the host cell. A primary vesicle forms in the host cell, which enables further development of intercellular hyphae in a susceptible interaction (BORHAN et al., 2001).

The objective of this study was to identify the heat shock time promoting greater release of zoospores / sporangia for infecting of purslane isolated (Talinum sp.), amarantus plant (Amaranthus deflexus), "jetirana" (Ipomoea nil) and purslane (Portulaca oleracea).
The experiments were performed at the Plant Pathology Laboratory of the Federal Institute Goiano campus Urutaí, Goiás State, Brazil. Isolates from Albugo spp. was collected in Urutaí, Goiás, infecting purslane, amarantus, "jetirana" and "onze-horas".

It was prepared for each sample one sporangia suspension by scraping the leaf lesions with the aid of a brush and distilled water, then was added one $\mathrm{mL}$ of Tween $80^{\odot}$. Subsequently, concentration was calibrated to $1.7 \times 10^{5}$ esporângia $\mathrm{mL}^{-1}$ using a Neubauer chamber.

The tests were performed with five treatments varying the heat shock time of 20', 30', 40', 50' and 60' alternating to each suspension initially at $5{ }^{\circ} \mathrm{C}$ for $1 \mathrm{~h}$ (refrigerator), after the end for $1 \mathrm{~h}$ too at $25^{\circ} \mathrm{C}\left( \pm 2{ }^{\circ} \mathrm{C}\right)$, and this essay was repeated by five times, completely randomized design (CRD). Then collected suspension is stirred with the aid of a dropper samples by an optical microscope to count the number of sporangia that we had realized zoospores in a total of 100 units (sporangia), sampling 20 times the evaluation. Each pot of each treatment was a repeat 5 times and, in each repetition, 20 readings would be done to obtain the average of each repetition for treatment. Two people performed the evaluation for after the average it is done. They were analyzed by $\mathrm{F}$ and Tukey averages compare test's $(\mathrm{P}=0.05)$.

The thermal variation induced the release of zoospores of less than half sporangia, reaching maximum amplitude of $38 \%$ of sporangia in the analyzed samples (Table 1).

In purslane leaves (infected by A. portulacae) the time of 20-30' promoted a greater number of zoospores released, whereas for the isolate from amarantus (infected by $A$. bliti) the time of 30' promoted statistically the highest release of zoospores; for the isolate from leaves of "jetirana" (infected by $A$. ipomoeae-panduratae) the time of $30-50$ ' promoted greater release of zoospores; and finally the isolate from "onze-horas" leaves (infected by A. portulacae) the time of 30-40' statistically promoted the highest percentage of release of zoospores, demonstrating a differential behavior per host in the release of zoospores (Table 1). In the field, periods of cold temperature in similar amplitudes stimulate the appearance of zoospores, besides mycelium it can be from the sporangial germination. Pagani et al. (2012) reported the importance of detecting white blister rusts in invasive plants, recording the occurrence of A. ipomoeaepanduratae in I. acuminata. This job we can also recording in Merremia aegyptia.

Of the spontaneous species collected in this study, the purslane and "onze-horas" host plant, in particular, both belonging to the family Portulacaceae, and infected by $A$. portulacae, it had the largest amplitudes of number of sporangia (30-40') that differed for zoospores 
(Table 1). Ass well as spontaneous species this work Ploch et al. (2010) suggested that Albugo from cruciferous could be widespread as an asymptomatic endophyte, refuge for source inoculum.

The detected oospores have thick walls (ALEXOPOULOS, 1996) and may as a structure of resistance and dissemination in adverse conditions when it was found. The purslane plant (A. portulacae) was the only one that detected oospores differing from the other plants. Petrie (1975) the sexual cycle, producing tough oospores with survival in terrible environmental conditions. The "onze-horas" plant presents lesions caused by Albugo spp. characterized by lesions on both leaf surfaces, irregular, powdery, white coloration. However, the plants carrion, amarantus, "jetirana" presented lesions caused by Albugo spp., characterized as lesions on the abaxial surface of leaves, irregular, powdery and white color aspect.

A morphological structure was identified in the suspensions submitted to the heat shock hyphae and sporangiogenic cells (Figure 1A). The sympodial branching of the sporangiophore was observed (Figure 1B), it was detailed and enlarged (Figure 1C) the plasmodium was released process has not differentiated zoospores (Figure 1D), there were differentiated plasmodium in zoospores located within the sporangium (Figure 1E) zoospore one was showed smooth and rough surface (Figure $1 \mathrm{~F}$ ) and oospore of thick wall (Figure 1G). The number of zoospores per sporangia wasn't measured, however in plant infected, when dehydrated the pustules could to contain masses of zoospores that upon re-hydration in water droplets release 4-6 zoospores. A primary vesicle forms in the host cell, which enables further development of intercellular hyphae in a susceptible interaction (BORHAN et al., 2001).

Owing purslane is a weed of greater frequency in crops and agricultural regions; it has frequently appeared in the region, so biologically the formation of sexual survival structures such as oospores (Table 2) suggests a more evident epidemiological importance. All host plant samples had asexual structures and / or sporangia (Table 2), which are typically responsible for epidemics during the vegetative and reproductive cycle of the host plant in the production fields (BERGAMIN FILHO; AMORIM, 2011). In the intermediate periods to the crop many plant pathogens can take refuge by infecting secondary hosts (AGRIOS, 1997) like those studied in this work.

In the majority of samples, the emission of signals for the development of secondary cycles of the disease in the same host or in crop hosts, due to the greater number of stomata in the abaxial face, causes the positioning of the pustules in the abaxial face (hypofile), except in the plant host at "onze horas", where it was observed on both leaves faces (amphigen) (Table 2).

The thermal variation caused release of zoospores of a maximum of $38 \%$ of the sporangia of the samples analyzed.

The conditions of 30-40 minutes promoted in all isolates the greatest impulse the transformation of the plasmodial area of the sporangium in zoospores by thermal shock. Some sporangia do not differentiate in zoospores even through thermal stimulation.

Because she is a weed of great frequency in the region, she developed sexual structures of survival serving as source of inoculum and of genetic variability for future infections in cultivated susceptible plants.

Table 1. Number of sporangia germinated by different types of thermal variation for different isolates of Albugo spp.*

\begin{tabular}{|c|c|c|c|c|}
\hline Treatments & $\begin{array}{c}\text { Purslane } \\
\text { (A. portulacae) }\end{array}$ & $\begin{array}{l}\text { Amarantus } \\
\text { (A. bliti) }\end{array}$ & $\begin{array}{c}\text { "Jetirana" } \\
\text { (A. ipomoeae-panduratae })\end{array}$ & $\begin{array}{l}\text { "Onze-horas" } \\
\text { (A. portulacae) }\end{array}$ \\
\hline $\mathrm{T} 1-10^{\prime}$ & $0,30 \mathrm{~b}$ & $0,25 \mathrm{~b}$ & $0,14 \mathrm{~b}$ & $0,21 \mathrm{~b}$ \\
\hline $\mathrm{T} 2-20$ & $0,38 \mathrm{a}$ & $0,19 \mathrm{c}$ & $0,15 \mathrm{ab}$ & $0,21 \mathrm{~b}$ \\
\hline $\mathrm{T} 3-30$ & $0,34 \mathrm{ab}$ & $0,33 \mathrm{a}$ & $0,18 \mathrm{a}$ & $0,33 \mathrm{a}$ \\
\hline $\mathrm{T} 4-40$ & $0,30 \mathrm{~b}$ & $0,22 \mathrm{bc}$ & $0,18 \mathrm{a}$ & $0,38 \mathrm{a}$ \\
\hline $\mathrm{T} 5-50^{\prime}$ & $0,19 \mathrm{c}$ & $0,17 \mathrm{c}$ & $0,18 \mathrm{a}$ & $0,24 \mathrm{~b}$ \\
\hline F Values & $\mathrm{F}_{4,95}=16,09 * *$ & $\mathrm{~F}_{4,95}=30,31 * *$ & $\mathrm{~F}_{4,95}=5,72 * *$ & $\mathrm{~F}_{4,95}=17,45 * *$ \\
\hline Coefficient of variation & $\mathrm{CV}=26,95 \%$ & $\mathrm{CV}=21,42 \%$ & $\mathrm{CV}=23,46 \%$ & $\mathrm{CV}=31,22 \%$ \\
\hline
\end{tabular}

* Averages followed by the same letters vertically, does not differ significantly.

Table 2. Presence and position of reproductive structures in different hosts infected with species of Albugo spp.

\begin{tabular}{lcccc}
\hline Características & $\begin{array}{c}\text { Purslane } \\
\text { (A. portulacae })\end{array}$ & Amaranthus (A. bliti) & $\begin{array}{c}\text { "Jetirana" } \\
\text { (A. ipomoeae-panduratae) }\end{array}$ & $\begin{array}{c}\text { "Onze-horas" } \\
\text { (A. portulacae })\end{array}$ \\
\hline Sporangia presence & present & Presente & present & present \\
Oospores presence & present & Absent & absent & absent \\
Pustule position & hipofile & hipofile & hipofile & amphigen \\
\hline
\end{tabular}




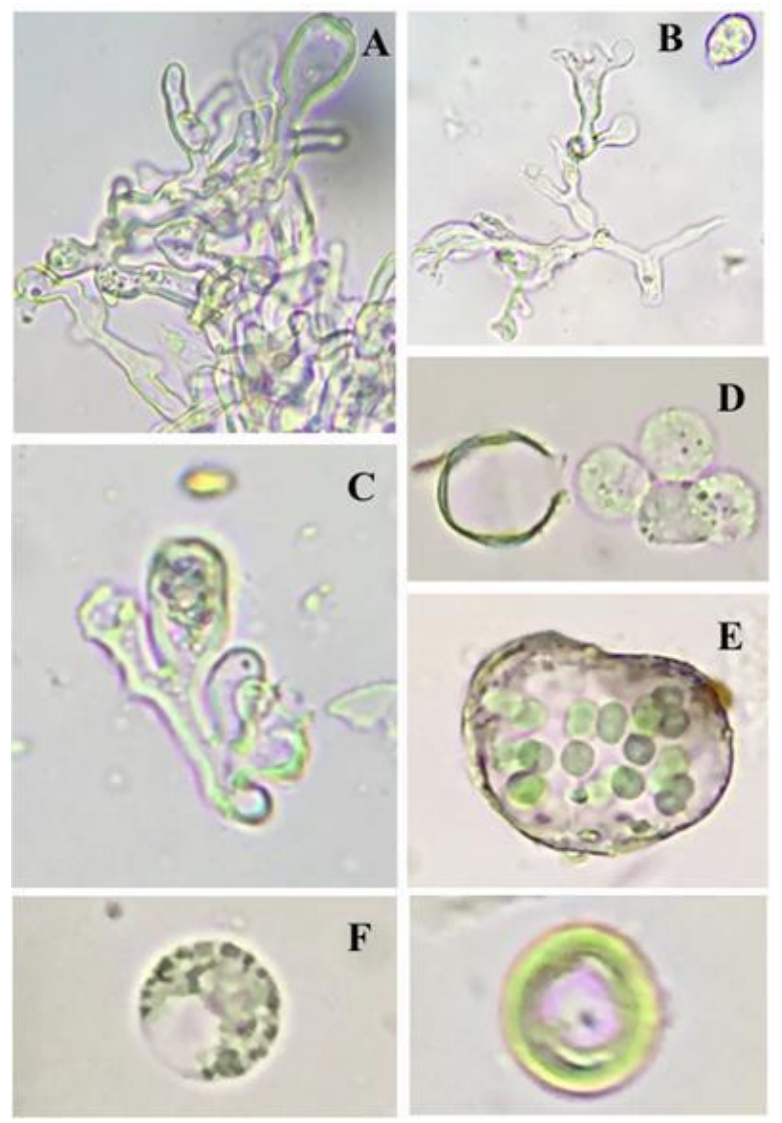

Figure 1. Morphological structures by Albugo sp. was identified in suspensions submitted to thermal variation. A. hyphae and sporangiogenic cells, B. sympodial branch of sporangiogenic cells, C. Extended sporangiogenic cell detail, D. undifferentiated plasmodium release process in zoospores, E. zoospores in different plasmodium located within the sporangium, F. Zoospore of smooth and rough surface, G. thick wall oospore.

\section{Referências Bibliográficas}

AGRIOS, G. N. Plant Pathology. 4. ed., Burlington: Elsevier, Academic Press. 1997. 606 p.

ALEXOPOULOS, C. J.; MIMS, C. W.; BLACKWELL, M. Introductory Mycology. New York-USA: John Wiley \& Sons, Inc., 1996. 865 p.
BERGAMIN FILHO, A.; AMORIM, L. Epidemiologia de doenças de plantas. In: Amorim, L., Rezende, J. A. M., Bergamin Filho, A. (Eds.). Manual de Fitopatologia: Princípios e conceitos. 4 ed. São Paulo-SP: Ceres, 2011, v. 1, p. 101-118.

BORHAN, H. M.; BROSE, E.; BEYNON, J. L.; HOLUB, E. B. White rust (Albugo candida) resistance loci on three Arabidopsis chromosomes are closely linked to downy mildew (Peronospora parasitica) resistance loci. Molecular Plant Pathology, London-UK, v. 2, n. 2, p. 87-95, 2001.

FARR, D. F.; ROSSMAN, A. Y. Fungal Databases, Systematic Mycology and Microbiology Laboratory, Ars, USDA. Washington, DC, USA: Available at: [http://nt.arsgrin.gov/fungaldatabases/], Accessed nov. 2018.

HOLUB, E. B.; BROSE, E.; TOR, M.; CLAY, C.; CRUTE, I. R.; BEYNON, J. L. Phenotypic and genotypic variation in the interaction between Arabidopsis thaliana and Albugo candida. Molecular Plant-Microbe Interactions, Virginia-USA, v. 8, n. 5, p. 916-928. 1995.

KIMATI, H.; AMORIM, L.; BERGAMIM FILHO, A.; CAMARGO, L. E. A.; REZENDE, J. A. M. Manual de Fitopatologia. 3. ed. São Paulo-SP: Agronômica Ceres. 1995. 919 p.

PAGANI, A. P. S.; DIANESE, A. C.; INACIO, C. A.; CAFE FILHO, A. S. Occurrence of white rust (Albugo ipomoeaepanduratae) on Ipomoea acuminata in the Brazilian mid-west. Brazilian Journal of Microbiology, São Paulo, SP, v. 43, n. 1, p. 306-308, 2012.

PETRIE, G. A. Prevalence of oospores of Albugo cruciferarum in brassica seed samples from Western Canada 1967-1973. Canadian Plant Disease, Montreal, Canadá, v. 55, n. 1, p. 19- 24, 1975.

PLOCH, S.; CHOI, Y. J.; ROST, C.; SHIN, H. D.; SCHILLING, E.; THINES, M. Evolution of diversity in Albugo is driven by high host specificity and multiple speciation events on closely related Brassicaceae. Molecular Phylogenetics and Evolution, Illinois-USA, v. 57, n. 2, p. 812-820. 2010. 